\title{
1997 - YEAR OF THE MONARCH IN SASKATCHEWAN
}

BERNIE GOLLOP, 2202 York Ave., Saskatoon, SK S7J 1 J1 and MIKE GOLLOP, 51 Welker Cresc., Saskatoon, SK S7N 3M3

The year 1997 was the year of the Monarch (the butterfly, that is) in Saskatchewan. This largest of our butterflies - rich, dark orange with prominent black veins on a $10-\mathrm{cm}$ wingspread - is usually a scarce commodity. It quickly became evident, however, that 1997 was different. The earliest report was by Maureen Somers at Waskesiu on 5 June. She also saw them on two or three of the next six days on the Saskatoon campus.

Then came the deluge. On 12 June Dennis Fisher, Lorriene and Craig Salisbury reported singles in their Saskatoon yards and Doug Paterson saw several at Fort Qu'Appelle;

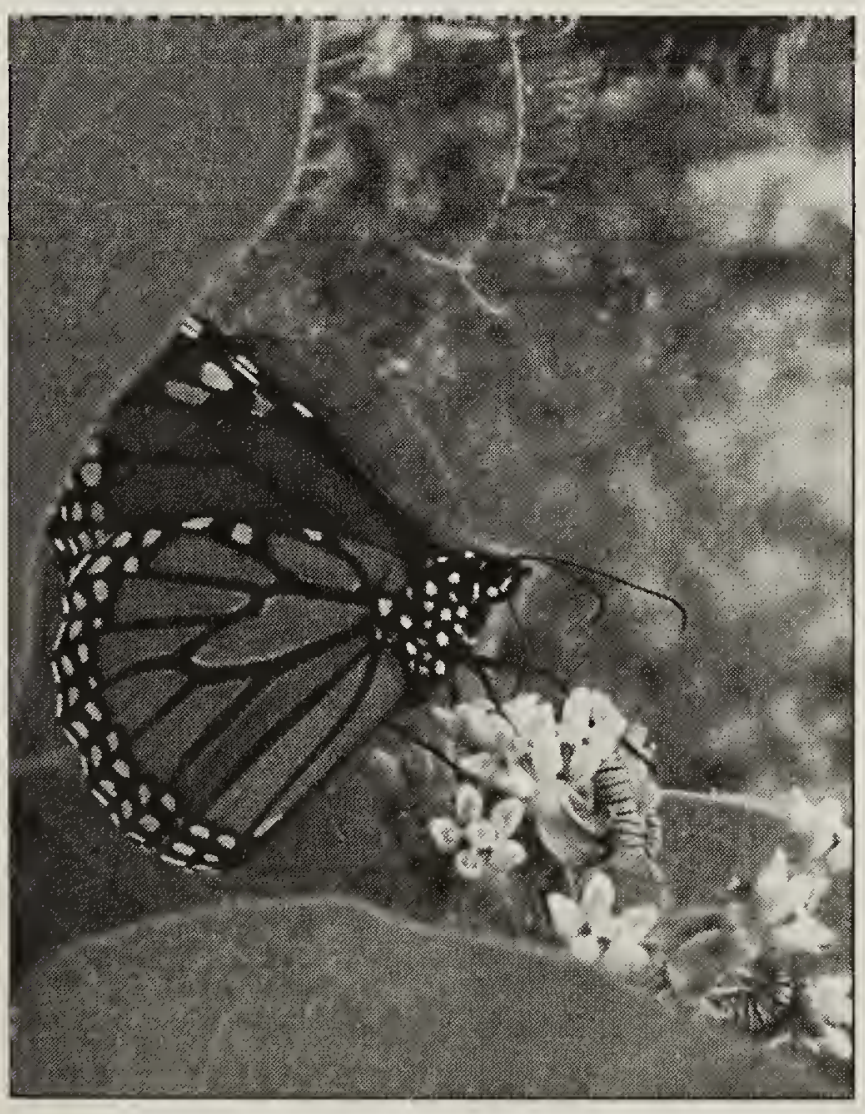

Monarch nectaring on Silky

Milkweed in Maine

Anna Leighton on 13 June, singles were reported from the Salisbury yard, from Chelan by John Kozial and from Ernfold by Ron Hooper. On 14 June, Fisher, the Salisburys and Jim Sullivan each saw one in Saskatoon; Kozial reported one from Bjorkdale; Hooper, one from Consul, and Lawrence Beckie up to three from Kenaston. On 15 June singles were seen at Kenaston, near Herbert by Hooper, at Saskatchewan Landing Provincial Park by Michael Williams and near Rosthern by Len Wassenaar.

Monarchs do not overwinter in Saskatchewan in any stage - egg, caterpillar, chrysalis or adult. The Monarchs we see in spring are the progeny of butterflies that left their overwintering sites above $3,000 \mathrm{~m}$ in the mountainous Oyamel Fir forests (Abies religiosa) west of Mexico City in March. (These forests are a glacial relict of our own boreal forest ecosystem.) The Monarchs laid eggs in states around the Gulf of Mexico during the last month of their lives and four weeks later some 100 million adults emerged and continued a mass migration northward to populate the eastern two-thirds of North America for another year. West Coast Monarchs winter in California.)

The 1997 spring migration of Monarchs was monitored on the Internet. The first US report read as follows: "Saw the first two monarchs in Galveston Bay, Texas, fluttering about the apple tree blossoms" on 


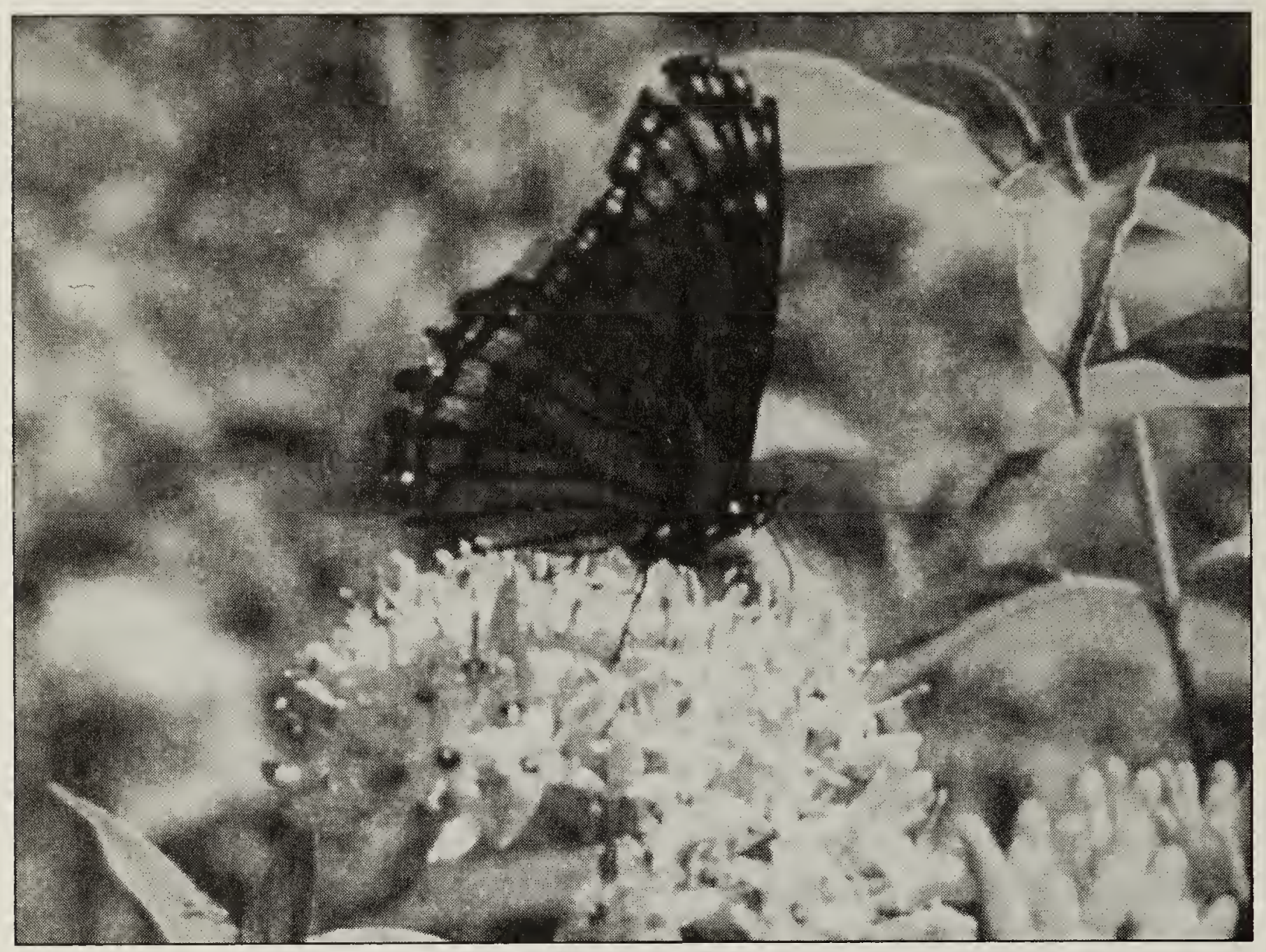

Viceroy. Much smaller than the Monarch, with a black line crossing veins on the hind wings and with one row of white dots, rather than two, along the outer margins of the wings. It has a frenetic, rather than leisurely, flight.

Anna Leighton

28 February (!!!!!). Most observations to 15 March were in southern Texas and Louisiana. By 15 April the vanguard stretched from Kansas to New Hampshire. During the first two weeks of May, Monarchs entered Canada in Ontario and Quebec; further west, they had only reached $\mathrm{Ne}$ braska. It would be another month before they were welcomed in Saskatchewan.

The 1996 Status Report of the Committee on the Status of Endangered Wildlife in Canada (COSEWIC) notes that "in Saskatchewan, where Monarchs are also scarce and irregular, none was reported in 1993 but in 1994 a small migration occurred with a total of 20 Monarchs being reported in the province." Normally, we (the authors) see one Monarch, if any, in a year. In 1997 we saw 53 between 17 June and $17 \mathrm{Au}$ gust. We found them on seven of nine 4 July Butterfly Counts (4JCs: part of an international survey, conducted within a month of 4 July); in 1996, we saw them on none of six. The Big Day was 31 July on the Roche Percee 4JC - 15 Monarchs.

To get a better idea of Monarch distribution in Saskatchewan, we contacted other people for their observations. Twenty-six reporters found Monarchs in 70 townships from the borders of Manitoba, the United States and Alberta, north to Prince Albert National Park (see map). They represent at least 40 dates and well over 250 individuals.

Ron Hooper reports that 1997 was a "good summer" for Monarchs in Saskatchewan. John Kozial summarized his 1990s experience with Monarchs in the Bjorkdale-Tisdale area as follows: 1990-1994: none; 1995: 2 or 3; 1996: 12; 1997: 25. 


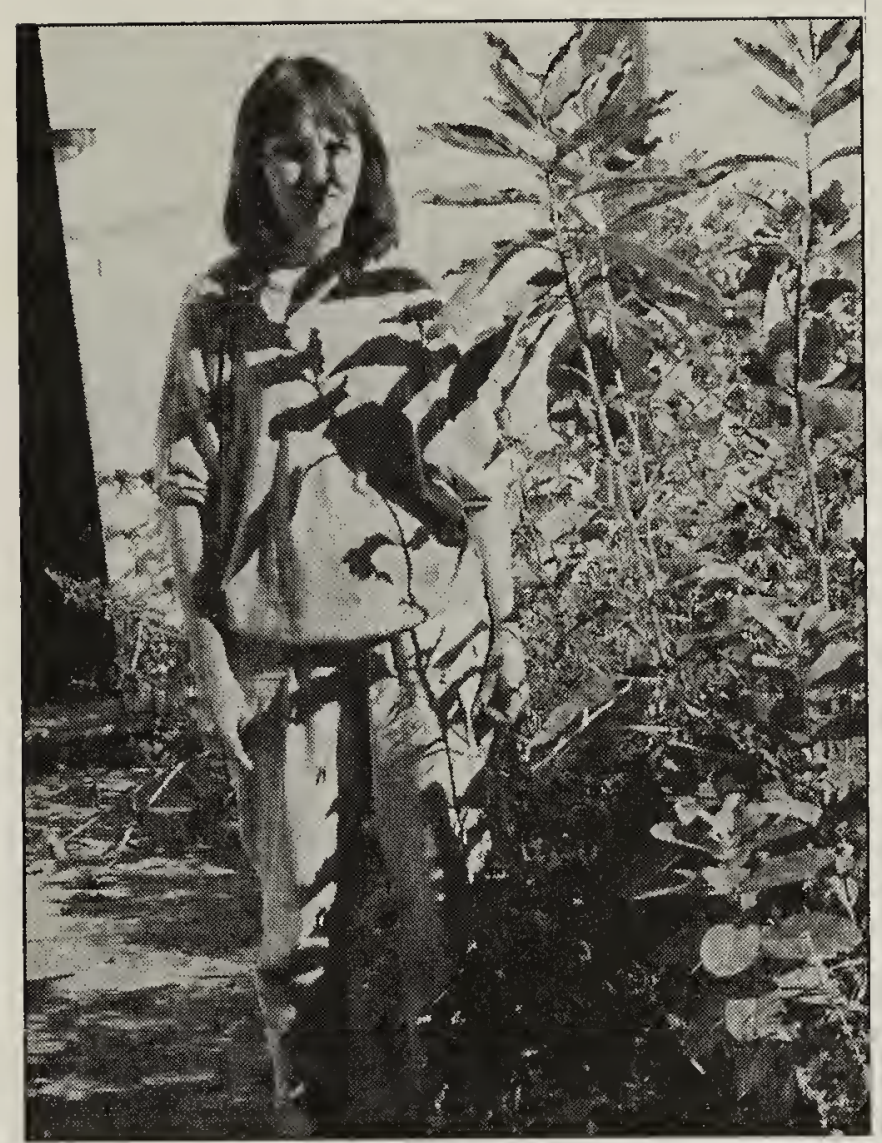

Joanne Blythe beside her tall and short milkweed patch at 1209 Munroe Ave., Saskatoon

Bernie Gollop

Robert Gebhart, a science teacher, saw them for the first time in his 20 years at Eastend, although he had checked milkweed patches regularly.

Over the years, the most northerly reports in the province have been from Cumberland House and the above record for Waskesiu. Looking further north, there is a single specimen for the Northwest Territories. The farthest-north breeding record for Monarchs in Saskatchewan is near Chelan $(40 \mathrm{~km}$ north and 210 $\mathrm{km}$ east of Saskatoon), where Don Hooper found adults emerging.

Breeding We know of five breeding records for 1997. Two of these demonstrate the butterfly's amazing ability to find milkweed - even if it is only a single plant. Paule and Dale Hjertaas had a Swamp Milkweed (Asclepias incarnata; not native to Saskatchewan) in a pot in the artificial pond of their Olson Place backyard in Regina. In June a Monarch showed up, laid four or five eggs on the plant, disappeared, and several minutes later, the same or another Monarch laid a few more eggs. Paule and Dale were away for July and when they returned there was no sign of Monarchs.

In Saskatoon in 1992, Joanne Blythe added Silky (Common) Milkweed seeds (Asclepias syriaca) to her Munroe Avenue backyard, which now has some 30 kinds of flowers and herbs. Nothing appeared, so she tried again the next year, producing one plant. The 13 stalks she has now (two about $2 \mathrm{~m}$ tall) are the product of this survivor. In June 1997 a Monarch visited her metrewide milkweed patch. A short time later at least five caterpillars came under study as they nourished themselves on the leaves. Eventually, two chrysalids were found. One, on the underside of a milkweed leaf, turned dark brown and stayed that way (see photo). However, a Monarch emerged from the other in late July or early August; its pupa was $5 \mathrm{~m}$ from the milkweed patch, lying on the upper side of a large leaf of Coltsfoot (Tussilago farfora).

South of Eastend, Robert Gebhart found 11 caterpillars in a milkweed patch along an irrigation ditch on 9 July. At the Gun Range, $3 \mathrm{~km}$ away, he found two more on milkweed on 10 July. On 22 July an irrigation surge came through, washing away larvae on the lower bank. Robert found three or four near the top of the ditch on 29 July. On 1 September no signs of Monarchs in any stage could be found.

Wayne Harris found caterpillars just north of Maple Creek on 1 August and near Roche Percee on 23 August.

In Saskatchewan, lilacs, standard and miniature (Syringa vulgaris), 


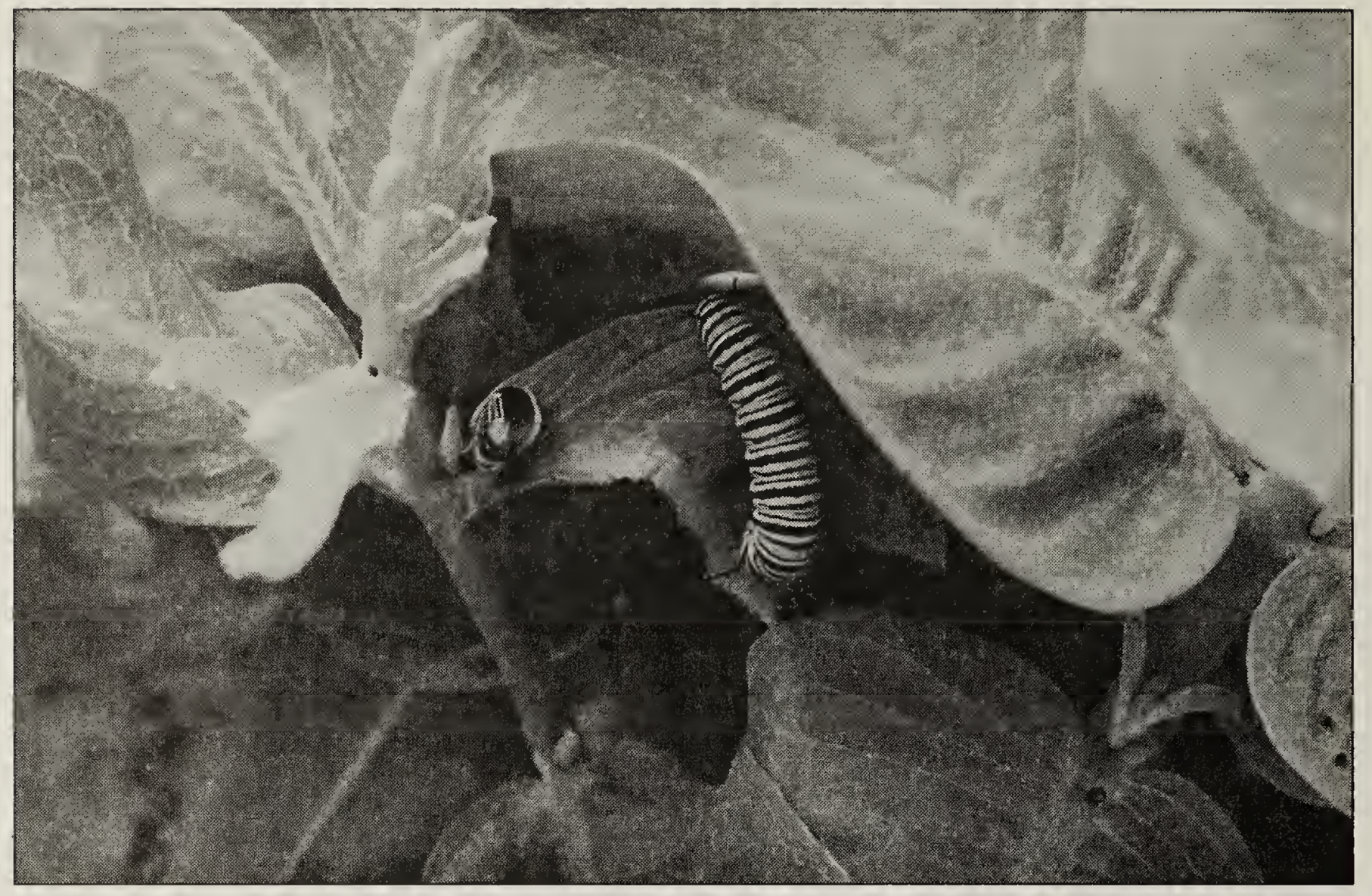

Caterpillar on Showy Milkweed near Eastend (Asclepias speciosa).

seemed to be the favourite nectaring plant of adults. Dennis Fisher's Monarch supped on the flowers of chives while Joanne Blythe's newly emerged adult concentrated on Red Clover (Albium schoenoprasum, Trifolium pratense). In the country, they were seen on alfalfa, Common Dandelion, snowberry, Tansy and Canada Thistle (Medicago sativa, Taraxacum officinale, Symphoricarpos, Tanacetum vulgare, Cirsium arvense).

The Monarchs we saw in June were in good shape - rich "plumage" and undamaged wings. Within a month they had faded and become ragged, but they had already laid eggs on their caterpillar host plants, milkweed and, to a lesser extent, dogbane (Apocynum). Most of the 15 adults on 31 July appeared to be freshly emerged - bright and in perfect shape; only a few were pale and tattered.

Fall Migration On 17 August, Bernie Gollop saw three Monarchs, in fresh condition, moving in an easterly direction over a piece of prairie on the north edge of Saskatoon; Mike Gollop saw one $3 \mathrm{~km}$ north of the city, and the Salisburys saw another in their yard. Combined, these records suggest the butterflies were starting to migrate. The only later dates we know of were Doug Paterson's 22 August Monarch in Regina; 30 August, when Michael Williams saw one $135 \mathrm{~km}$ east of Saskatoon, gaining altitude and heading southeast; 7 September - Bob Gebhart discovered one in Eastend, and 9 September when Wayne Harris found one near Roche Percee.

So, excluding stragglers, Monarchs were with us for about two months in 1997 - mid-June to midAugust. Their stay began with a generation spawned from eggs laid in Texas and Louisiana (and perhaps further north) and ended with a new generation of adults emerging in Saskatchewan and migrating south. They will live until they have laid eggs in the southern states in the 


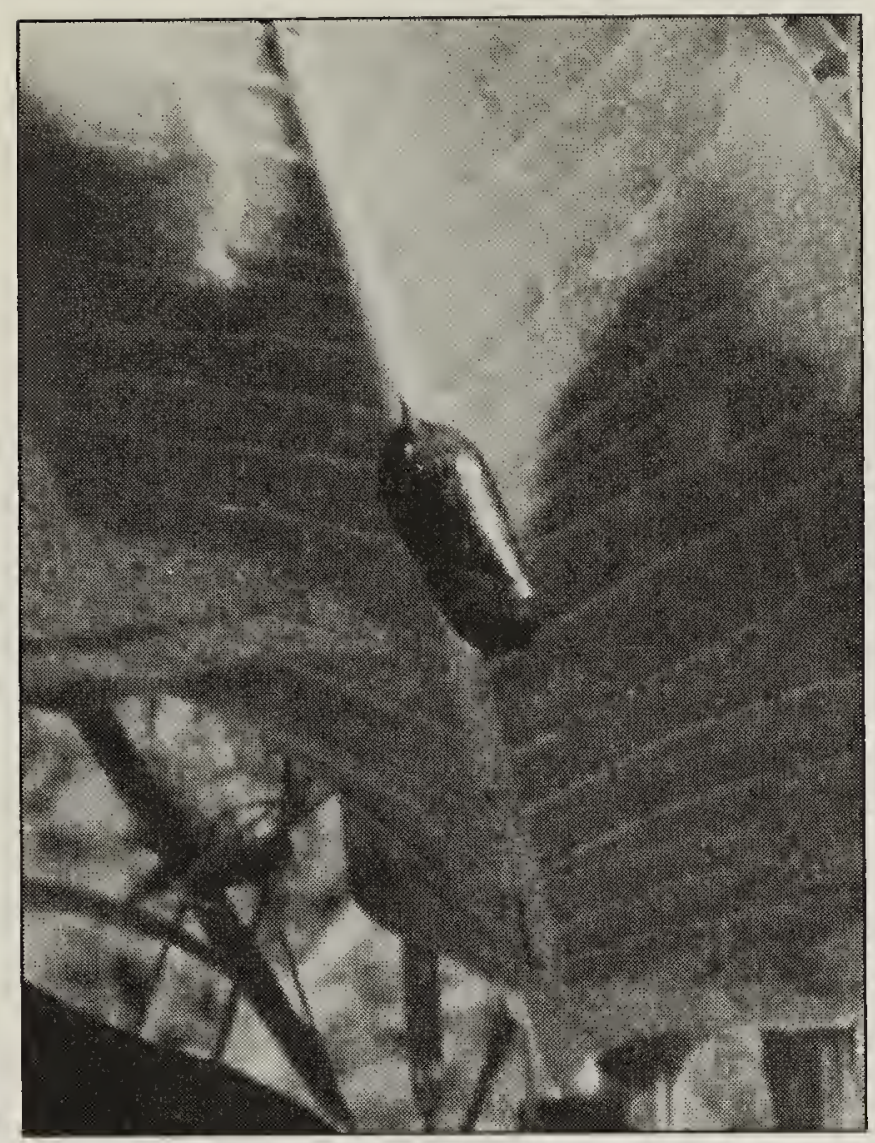

Dead chrysalis on underside of milkweed, Munroe Ave., Saskatoon

Bernie Gollop

spring of 1998. Only the Monarchs "born" in Saskatchewan, then, fly $3500 \mathrm{~km}$ south, possibly guided by geomagnetic forces, during their three-month migration. They make flights up to $130 \mathrm{~km}$ per day at speeds as fast as $32 \mathrm{~km}$ per hour and altitudes to $3 \mathrm{~km}$. They will spend about four months in Mexico (late November to early April) and it will take them and their progeny about three months to repopulate the north countries.

The major factor allowing many Monarchs to reach Saskatchewan may well be weather. The previous year's weather has to have been good enough to allow at least an average number of Monarchs to reach Mexico. Winter weather has to have been such that there is low mortality and spring weather in the United States has to have been good for reproduction. The year 1979 was also a good year for Monarchs (as well as Painted Ladies) around Saskatoon.
Paul Klassen and David Delf noted more Monarchs than usual in Manitoba in 1997 with late dates of 13 and 14 September. In southern Alberta, Ted Pike did not see one in the course of considerable field work. Our Alberta observations were of two, 1 July, on the South Saskatchewan River at Hwy 41, south of Empress, and singles in Medicine Hat on 15 and 17 July. Bob Kreba saw two along the South Saskatchewan River south of Suffield, Alberta, 18 June.

Conservation Status Monarch migration and overwintering concentrations were declared a Threatened Phenomenon - the only event ever so designated - in 1983 by the International Union for the Conservation of Nature and Natural Resources and the World Wildlife Fund (WWF). Such a phenomenon is defined as a spectacular aspect of the life history of an animal or plant species involving a large number of individuals that is threatened with impoverishment or demise. The species per se need not be in peril; rather, the phenomenon it exhibits is at stake. The wintering aspect is well known. An example of the southward migration phase would be an 1885 observation from Brigantine, NJ: "almost past belief ... millions is but feebly expressive ... miles of them is no exaggeration." Further south, some Monarchs may successfully cross the Gulf of Mexico using a network of 3,000 rest stops referred to as oil and gas rigs.

The vulnerability of the Monarch has been compared to that of the Passenger Pigeon. In 1995 it was featured in a set of Canadian stamps entitled Migratory Wildlife. Congress is considering its designation as the national insect of the United States. The WWF has included this butterfly in its set of six 1997 stamps depicting animals and plants at risk. 


\section{MONARCH BUTTERFLY MIGRATION - 1997}
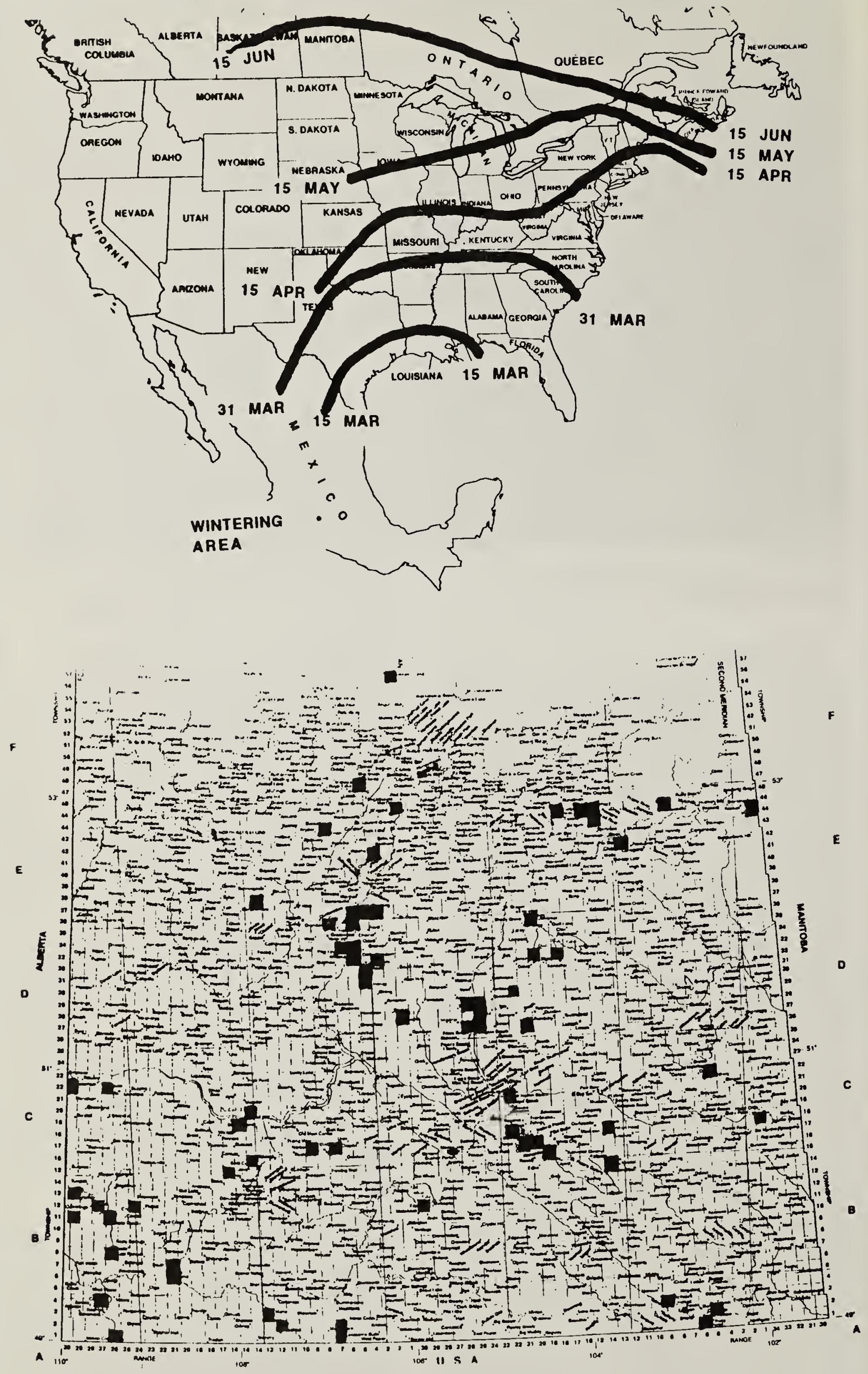

Map 1 (top): Monarch spring migration (from the Internet).

Map 2 (bottom): Adult Monarch distribution in Saskatchewan by township, based on 1997 obversations. 


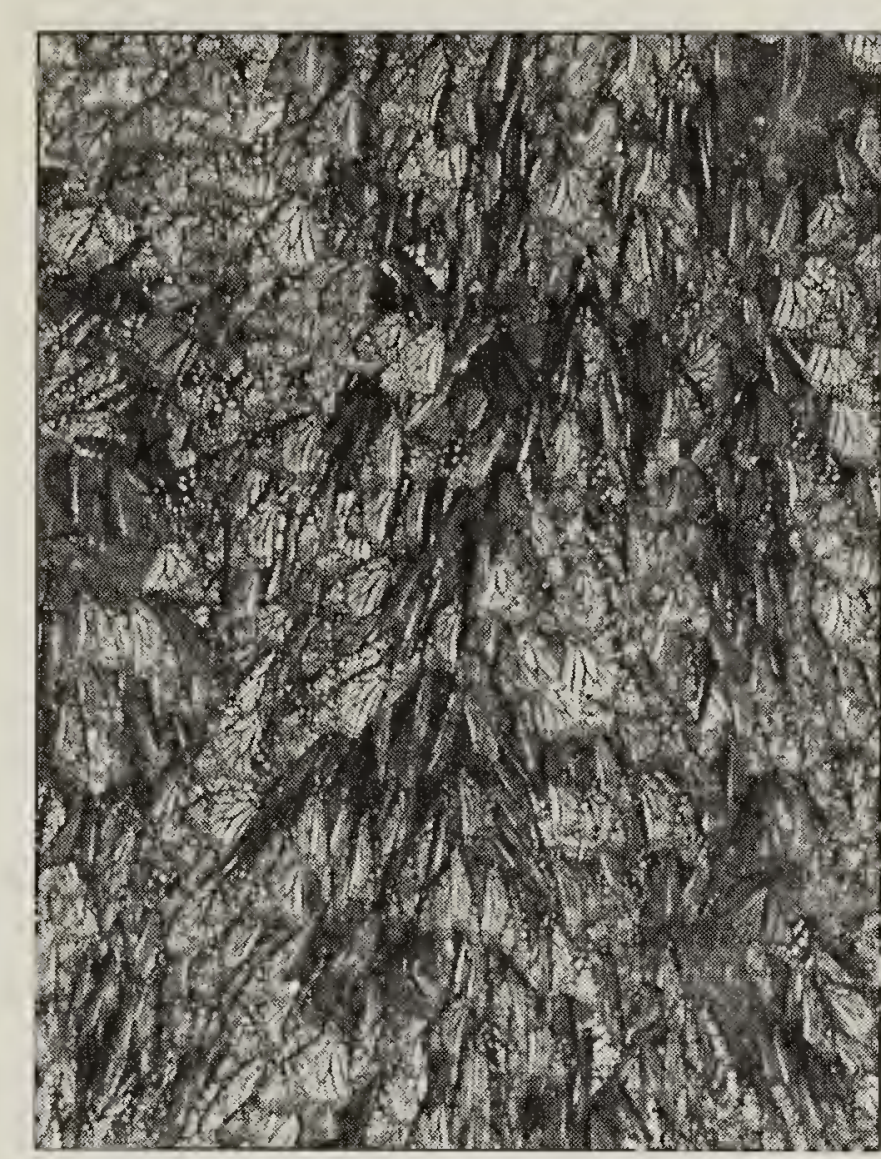

Monarch wintering concentrations on Oyamel Fir in Mexico

Keith Hobson

In 1997 the Monarch became one of three butterflies - and the only one occurring in western Canada to be put on the COSEWIC list. It is classified as Vulnerable because, in Canada, its primary caterpillar host plant (milkweeds) is officially a noxious weed in some provinces and is being eradicated. (Silky or Common Milkweed is so designated in Saskatchewan.) In Mexico, Oyamel Fir is harvested as valuable timber and firewood and the butterfly's 10 wintering sites have no effective protection. Most are under a half hectare (1.2 acres) each and all are concentrated in an $800-\mathrm{sq}-\mathrm{km}$ area - just over a quarter the size of Prince Albert National Park. According to a December 1997 TV special on the Monarch, up to 7000 tourists a day visit the two sites in Mexico open to the public. One roost in California hosts 60,000 visitors a season.

If Canadian Monarchs were restricted to only a few of these Mexican colonies, the threat to our population would be even greater.
Len Wassenaar, National Hydrology Institute, and Keith Hobson, Canadian Wildlife Service - both with Environment Canada, Saskatoon are investigating this possibility. They are analyzing the ratio of deuterium to hydrogen in the wings. Due to climatic factors, this ratio occurs as a gradient, at least in plants, songbirds and butterflies, from north (lowest) to south (highest). In butterflies, the value of the ratio remains constant after the adults emerge, permitting researchers to determine at what latitude butterflies in wintering congregations originated. Preliminary results indicate that Canadian Monarchs are widely distributed through the wintering sites.

In California, although much smaller numbers of Monarchs are involved, the picture is not much better. They congregate primarily on Blue Gum (Eucalyptus globulus) trees along $900 \mathrm{~km}$ of coast. Efforts are now being made to eradicate the Eucalyptus - an Australian import - as a "pest" tree. However, multimillion-dollar developments - for housing, motels and recreation complexes - may be an even greater threat. At least 21 roosting sites have been destroyed; about 130 remain.

We would much appreciate hearing about other Monarch observations in the prairie provinces, both for 1997 and 1998 - numbers and places (mainly) but also dates, as close as possible. Phone: (306) 343-1027; email is mgollop@sk.sympatico.ca; regular mail, as above.

Acknowledgments Our thanks to the people named above and to the following for reporting observations: Ken Coutu, Mel Fitch, John Lake, Ken Pivnick, Don Reynard, Keith Roney, Angela Salzl, Lloyd Saul, Phil Taylor and Jim Wood. Special thanks also to those contributing photographs and to Anna Leighton 

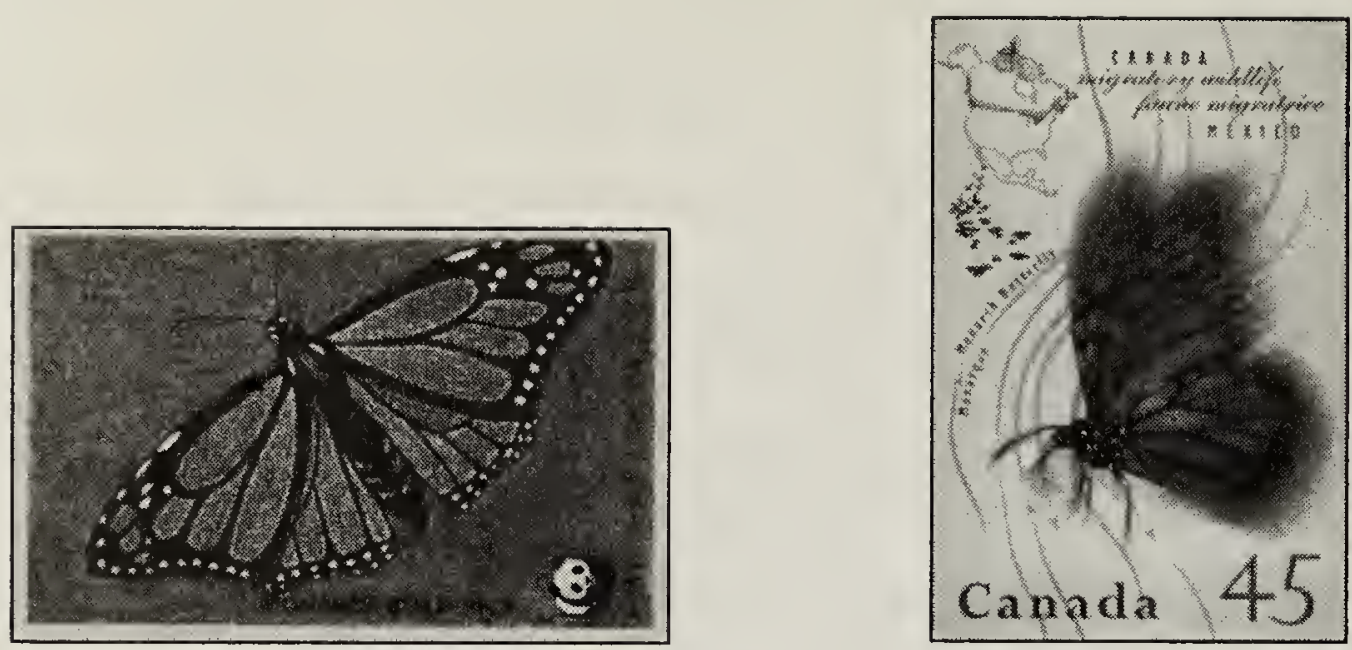

Left: Monarch on World Wildlife stamp

Right: Monarch from Canadian stamp set - Migratory Wildlife

for writing the accompanying milkweed article.

Most of the non-Saskatchewan information in this article came from two publications and two web sites:

From papers delivered at a conference in California and published as "Biology and conservation of the Monarch butterfly," edited by Stephen Malcolm and Myron Zalucki. Natural History Museum of Los Angeles County. 1992. 419 pages.

From an 85-page article by Lincoln Brower entitled "Understanding and misunderstanding the migration of the Monarch butterfly (Nymphalidae): 1857-1995" in Volume 49 (1995) of the Journal of the Lepidopterists' Society.
The web site for Monarch migration is:

http://www.learner.org/content/k12/ jnorth/1997/critters/mona rch/ 858039639. html

For the 19-page status report leading to the Monarch's Vulnerable designation in Canada, see:

http://www.keil.ukans.edu/ monarch/ temp/canada/monarch/1.htm.

More accessible additional reading, hopefully in library or bookstore, may be found in:

The nature of Monarch butterflies. 1997. By Eric Grace. Greystone Books, Vancouver, BC. 114 pages.

The great butterfly hunt. 1990. By Ethan Herberman. Simon \& Schuster, NY. 48 pages.

Birds are subject to invasion by one or more of the following parasites: fungus, amoeba, flagellate, plasmodium, spirochaete, trypanosome, encapsulated tongue worm, fluke, roundworm, spiny-headed worm, tapeworm, tongue worm, leech, flea, feather louse, fly larva, louse fly, mite and tick. 